International Journal of Engineering Technology and Scientific Innovation

ISSN: 2456-1851

Volume: 05, Issue: 04 "July-August 2020"

\title{
EFFECT OF OXYGEN - AIR RATIO ON THE GASIFICATION OF MUI BASIN COAL USING FIXED-BED GASIFIER
}

\author{
${ }^{1}$ Mr. Oyugi George, ${ }^{2}$ Eng. Dr. Hiram Ndiritu, and ${ }^{2}$ Dr. Benson Gathitu
}

${ }^{1}$ Technical University of Mombasa

${ }^{2}$ Jomo Kenyatta University of Agriculture and Technology

DOI: 10.46609/IJETSI.2020.v05i04.002 URL: https://doi.org/10.46609/IJETSI.2020.v05i04.002

\begin{abstract}
Gasification is a thermo-chemical process that produces syngas, which is a mixture of hydrogen, methane and carbon monoxide from coal or biomass. The proportions of this mixture is determined by, among other factors, the oxidizer used, which may include air, oxygen, steam or their mixtures in predetermined proportions. In this research, a mixture of oxygen and air was used to gasify coal from Mui Basin in Kenya, using fixed-bed dry-fed gasifier. When oxygen content in the oxidizing agent was varied between $21 \%-100 \%$, the optimum oxygen concentration was found to be $61 \%$, at which the low heating value of the syngas was 12.98 $\mathrm{MJ} / \mathrm{m}^{3}$, and the cold gas efficiency was $75.2 \%$. This research was aimed at enhancing the exploitation of Mui Basin coal for electricity generation for Kenyan citizens and to add to the wealth of knowledge on gasification technology.
\end{abstract}

Keywords: Cold gas efficiency, Gasifying agent, Producer gas, Syngas

\section{INTRODUCTION}

Access to energy directly affects quality of life and influences social equality and economic growth. Countries with low per capita energy consumption experience low per capita gross domestic products (GDP) [1]. Coal is the largest fossil fuel resource in the world [and many countries use coal for energy production due to its availability, reliability, and relative low cost [2, $3]$. In the year 2017 , coal provided $35 \%-40 \%$ of the global electricity generation [4, 5]. In Kenya, $68 \%$ of the total energy supply is from biomass, petroleum - $22 \%$, electricity - $9 \%$ and other sources - $1 \%[1,6]$.

The major challenge in using coal is the considerable emissions of $\mathrm{CO}_{2}, \mathrm{SOx}$, NOx, and 


\section{International Journal of Engineering Technology and Scientific Innovation}

ISSN: 2456-1851

Volume: 05, Issue: 04 "July-August 2020"

particulates, which contribute to climate change and air pollution [7]. By the year 2017, coal accounted for $44.2 \%$ of the total global $\mathrm{CO}_{2}$ emissions from fossil fuels, which is about half of the global greenhouse effect, while SOx and NOx cause acid rain and general water contamination $[4,8]$. This has necessitated a need for better and environmentally friendly technologies for utilization of coal.

Kenyan reference electrical power demand is projected to rise from 1,754 MW in 2017 to 6,638MW in 2037 [14]. Moreover, in order to meet this increased demand, the total installed capacity should increase from 2,234.83 MW to 9,932.44 MW in the same period. Gasification of the discovered coal in Mui Basin, Kitui County, could be used as an additional source of power to help increase the installed capacity thus increasing electric supply to the citizens.

The Mui Basin coal ranges from lignite to bituminous [9]. Gasification of coal is particularly appropriate for utilization of low-rank coals like lignite, given their high gasification reactivity [10]. Gasification is the conversion of any carbon-containing solid fuel like coal, into a gaseous product called producer gas, in the presence of gasifying agents. These agents include oxygen, air, steam, carbon dioxide or their mixtures in different proportions. This producer gas is a mixture of combustible product called synthesis gas (syngas) consisting of $\mathrm{CO}, \mathrm{H}_{2}$, and $\mathrm{CH}_{4}$ gases, and the non-combustible by-products which include $\mathrm{H}_{2} \mathrm{O}, \mathrm{CO}_{2}$, and $\mathrm{N}_{2}[11,12]$. Syngas is considered a clean fuel and more environmentally friendly compared to other fossil fuels due to production of less $\mathrm{SOx}, \mathrm{NOx}$ and $\mathrm{CO}_{2}$ emissions and can be utilized in chemical industry, power production, or for domestic applications [13].

In order to use coal syngas for power generation, its chemical composition and the heating value are of utmost importance. Many factors like nature and flow rate of the gasifying agent, the quality and particle size of coal, the pressure, and temperature in the reactor, affect the syngas properties, the gasification process efficiency and the equipment used [15]. Variations of the gasifying agents used in gasification depends mainly on the type of coal and the required quality and application of syngas. Different coal ranks and qualities like lignite, bituminous, anthracite require different amounts of the gasifying agents in order to produce quality syngas [16]. Furthermore, depending on the application of the syngas, these oxidizing agents may be varied to produce the desirable composition of the syngas for the desired application [17].

\section{EFFECT OF GASIFYING MEDIUM ON GASIFICATION PROCESS}

Lee H. et al [18] developed a model to analyze chemical reaction processes in a dry-feeding entrained-bed coal gasifier as a function of $\mathrm{O}_{2} /$ coal ratio, steam/coal ratio, and operating pressure. They observed that increasing $\mathrm{O}_{2}$ concentration increased carbon conversion rate leading to enhanced syngas yield. They also noted that, increasing steam concentration slowly 


\section{International Journal of Engineering Technology and Scientific Innovation}

ISSN: 2456-1851

Volume: 05, Issue: 04 "July-August 2020"

increased carbon conversion efficiency during the initial reaction stages but the rate improved with time. This was because increasing steam concentrations led to decrease in the reactor temperature, and cold gas efficiency, due to high heat capacity of steam. As a result, the generated syngas concentration is low save for hydrogen due to the high steam concentration.

Park T. J. et al [19] studied the characteristics of entrained-flow coal gasifier. In their research they found that, the $\mathrm{O}_{2}$ /coal ratio is critical to carbon conversion for a short residence time reactor, since the endothermic gasification reactions were supported by the heat produced from exothermic reactions. They concluded that for such a gasifier $\mathrm{O}_{2} /$ coal ratio of between 0.8 and 0.9 was optimum. In addition, they realized that temperature distribution inside reactor depended upon the feed rate of coal and oxygen unless heat losses were considered. They showed that reactor temperature rose with increasing in $\mathrm{O}_{2} /$ coal ratio, consistent with the findings of Biagini E. et al [20].

Alina Zogala [11] did a thermodynamic equilibrium simulation to determine factors affecting syngas composition from coal gasification. He used coal, of different ranks, from four different Polish coal mines. He used three forms of gasifying agents: mixtures of steam-pure oxygen, steam-air and air-pure oxygen. He observed that raising the concentration of $\mathrm{O}_{2}$ in the gasifying agent led to significant rise in molar yield of $\mathrm{CO}, \mathrm{H}_{2} . \mathrm{CO}_{2}$ and $\mathrm{H}_{2} \mathrm{O}$, though the yield of $\mathrm{CO}_{2}$ exceeded that of $\mathrm{H}_{2} \mathrm{O}$ at higher $\mathrm{O}_{2}$ concentrations. Similar trends were seen when using steam in the gasifying agent. Much yield in $\mathrm{H}_{2}$ was realized when $\mathrm{H}_{2} \mathrm{O}$ concentrations were increased than when only $\mathrm{O}_{2}$ and air were used. His research, however, assumed that the gasification processes were isothermal (at $700^{\circ} \mathrm{C}$ ) in the reactor, which is not the case in the actual practice.

Babu B. V. et al [21] modeled a biomass gasifier to show the effects of O2/air and steam/air ratio on gasification process. Their results were in agreement with those of Alina Zogala [11]. But they went further and found that the calorific value of the syngas increased with increasing $\mathrm{O}_{2} /$ air ratio but decreased with increasing steam/air ratio and that the reaction temperature also increased for preheated air intake. Their model was however based on wood as the feedstock, which is high in volatile matter and moisture compared to coal. Their findings were in agreement with the findings of Haibin Li et al [22] who studied the effect of oxygen flow rate on gasification products.

Weihong Yang et al [23] analyzed the influence of a preheated feed air on the performance of a fixed-bed biomass gasifier. They found out that when higher air temperature were used, the temperatures of the solid fuels rose from room to peak temperature more quickly compared to when lower air temperature were used, indicating that a fast ignition occurs. They also observed that the peak temperatures were lower when higher feed air temperatures were used. This was 
because the ignition temperature was much lower when high feed gas temperatures were used. Preheating the feed air to these high temperatures however added to the cost of the gasification system due to specialized materials needed to contain such high temperatures.

Idowu Adeyemi et al [24] and Leila Emami et al [25] in their studies showed that increase in reactor temperature and pressure led to the formation of more $\mathrm{CO}, \mathrm{H}_{2}$ and higher calorific value due to improved endothermic reactions between char and steam and carbon dioxide. Muhammad Shahbaz et al [26] also observed that increase in gasification temperature improved the carbon conversion rate in biomass up to about $725^{\circ} \mathrm{C}$ beyond which the conversion rate starts reducing.

\section{Gasification Reactions}

When coal is injected into a high-temperature gasifier, a series of physical and chemical processes occur in the gasifier. The particles are quickly heated, the moisture is evaporated, the volatile matter in the coal is devolatilized, and the char is burnt or gasified. The gases released from the coal particles will also react with each other depending on the surrounding environmental conditions and their intrinsic kinetics mechanism. These reactions are either exothermic or endothermic [27]. Below are some of the major chemical reactions that take place during gasification $[28,29]$.

$$
\begin{array}{ll}
\mathrm{C}+\mathrm{O}_{2} \rightarrow \mathrm{CO}_{2} & (-393 \mathrm{MJ} / \mathrm{kmol}) \\
\mathrm{C}+1 / 2 \mathrm{O}_{2} \rightarrow \mathrm{CO} & (-111 \mathrm{MJ} / \mathrm{kmol}) \\
\mathrm{C}+\mathrm{H}_{2} \mathrm{O} \leftrightarrow \mathrm{CO}+\mathrm{H}_{2} & (+131 \mathrm{MJ} / \mathrm{kmol}) \\
\mathrm{C}+\mathrm{CO}_{2} \leftrightarrow 2 \mathrm{CO} & (+172 \mathrm{MJ} / \mathrm{kmol}) \\
\mathrm{CO}+1 / 2 \mathrm{O}_{2} \rightarrow \mathrm{CO}_{2} & (-283 \mathrm{MJ} / \mathrm{kmol}) \\
\mathrm{H}_{2}+1 / 2 \mathrm{O}_{2} \rightarrow \mathrm{H}_{2} \mathrm{O} & (-242 \mathrm{MJ} / \mathrm{kmol}) \\
\mathrm{CO}+\mathrm{H}_{2} \mathrm{O} \leftrightarrow \mathrm{CO}_{2}+\mathrm{H}_{2} & (-41 \mathrm{MJ} / \mathrm{kmol}) \\
\mathrm{CO}+3 \mathrm{H}_{2} \leftrightarrow \mathrm{CH}_{4}+\mathrm{H}_{2} \mathrm{O} & (-206 \mathrm{MJ} / \mathrm{kmol})
\end{array}
$$

\section{METHODOLOGY}

\subsection{The Experimental Set-up}

The experimental set-up entailed an air blower that pumped atmospheric air into a mixing chamber where it mixed with oxygen from a cylinder. The oxygen used was bottled pure oxygen purchased from an industrial gas supplier. The oxygen/air mixture was then directed into the 
gasifier. Fig.1 shows the schematic representation of the set-up of the experiment while Fig. 2 shows the actual experimental set-up.

The gasifier had a constant feed rate of coal at a predetermined flow rate and it was dry-fed from above through a hopper. There were type-K thermocouples, placed strategically along the height of the gasifier, to measure the temperature in the reactor and freeboard sections of the gasifier. These measuring devices were connected to a data recording system which was coupled to a computer to help analyze the results.

At the top of the gasifier was an outlet for the producer gas. This hot gas was taken through an evaporator where it cooled before sampling. The product gas was sampled occasionally at a predetermined time intervals of 30 minutes, into Portable Multi- gas Analyzer where its composition was determined especially $\mathrm{CO}, \mathrm{H}_{2}, \mathrm{CO}_{2}, \mathrm{CH}_{4}, \mathrm{H}_{2} \mathrm{O}$, and $\mathrm{N}_{2}$. This data was then used to analyze the quality of the syngas and the performance of the gasification system by calculating parameters like heating values, and cold gas efficiency. Due to the presence of harmful gases like $\mathrm{CO}$ gas, the experiment was conducted in an open area (well ventilated) to ensure safety of the personnel.

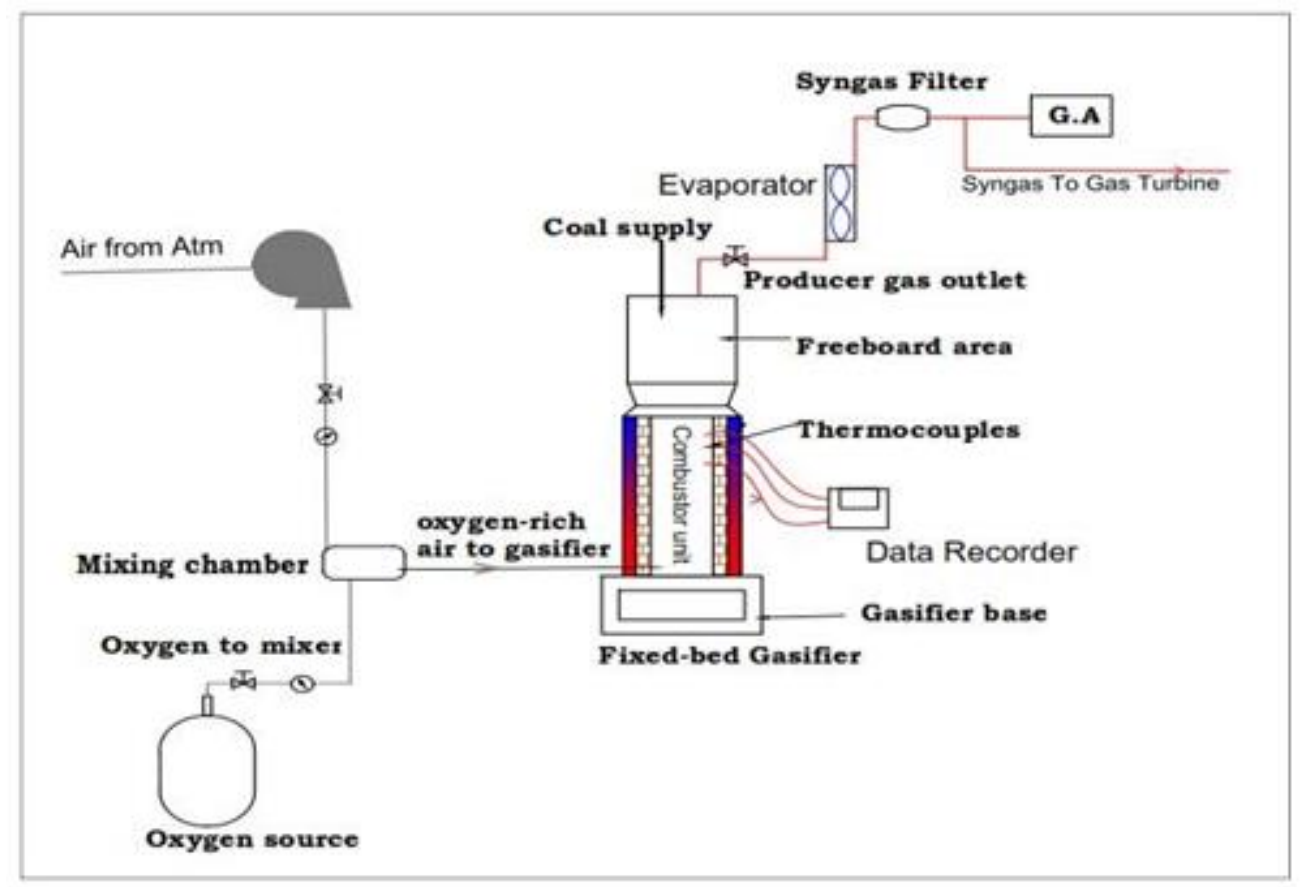

Fig. 1: The schematic diagram of the experimental set-up 


\section{International Journal of Engineering Technology and Scientific Innovation}

ISSN: 2456-1851

Volume: 05, Issue: 04 "July-August 2020"

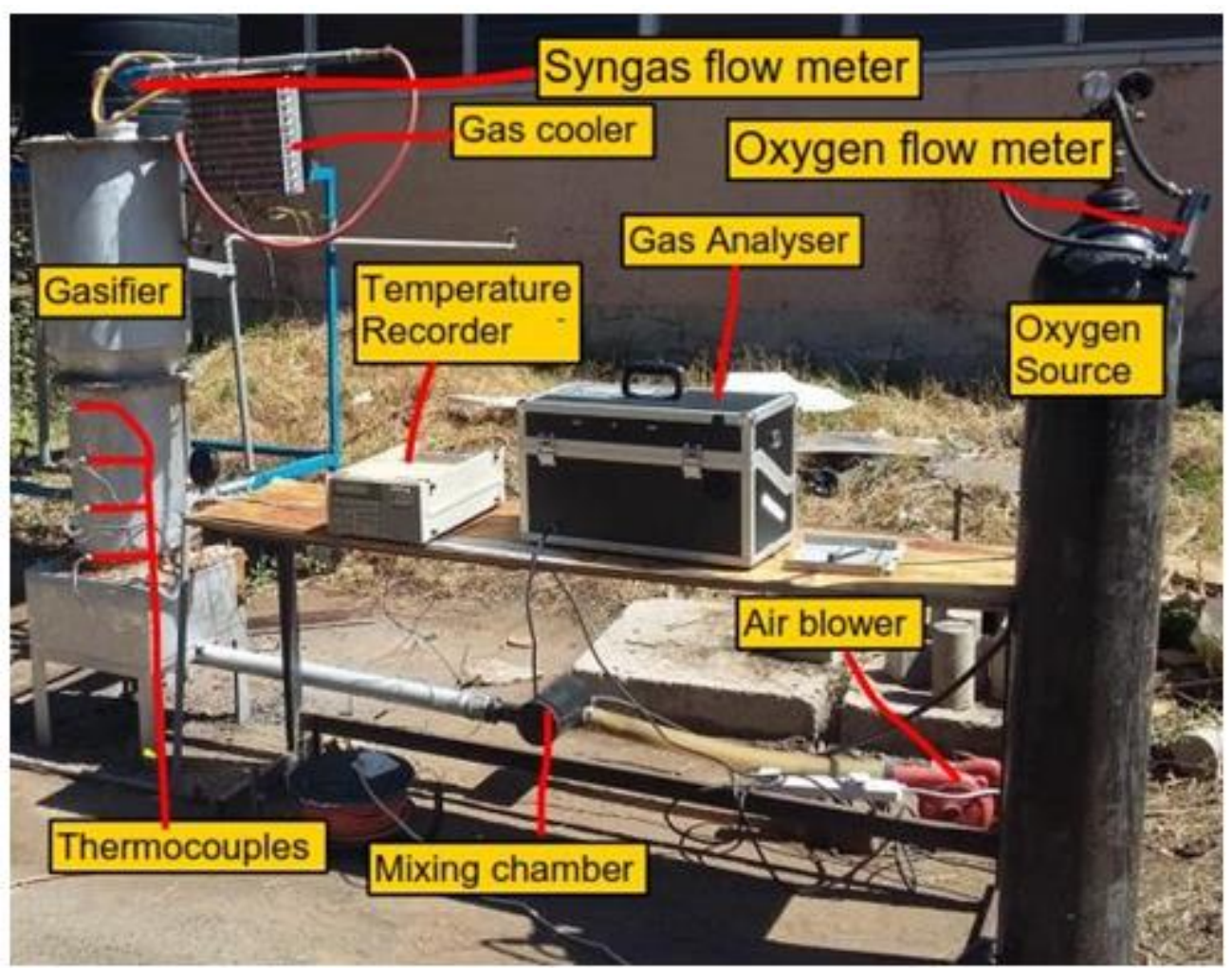

Fig. 2: The experimental set-up

\subsection{Experimental Procedure}

The experiments were conducted using an existing bench-scale fixed-bed dry-fed gasifier operating at a pressure of 1 atmosphere (1.01325 bar). Coal feeding rate was maintained at a constant value of $6 \mathrm{~kg} / \mathrm{h}$. The gasifier used was autothermic without any external source of heat. The heat used in all the reactions was thus generated within the gasifier from the exothermic gasification reactions.

To investigate the effect of oxygen-enriched air (OEA) as the gasifying agent on Mui Basin Coal, air at equivalence ratio (ER) of 0.3 was used as the initial oxidizer. Thus, initial $\mathrm{O}_{2}$ concentrations of $21 \%$ was actually the quantity of oxygen in the amount of air equivalent to $30 \%$ of the stoichiometric air needed to completely burn the coal feed. This amount of air was held constant and the oxygen content increased from an external source in steps of $10 \%$ concentrations. This ER value of 0.3 was taken since, from the screening experiments conducted, at this value of ER the hydrogen concentrations in producer gas was high while carbon dioxide and nitrogen concentrations were low. This also agreed with the findings of Bingxi Li et al [30]. This reduced input of excess nitrogen related with higher input of air concentrations while also 
reducing the cost of oxygen used associated with pure oxygen gasification. The concentration of oxygen by volume in the gasification air was varied from $0.21(21 \%)$ upwards up to oxygen/air ratio of 1.0, with air feed maintained constant at ER of 0.3. At each interval, the temperatures, gas composition, and gas yields were recorded.

\subsection{Gasification performance}

The quality of the syngas was measured in terms of its lower heating value (LHV). The LHV of syngas is dependent on the percentage quantities of $\mathrm{CO}, \mathrm{H}_{2}$ and $\mathrm{CH}_{4}$ in the producer gas and was calculated from the relation in Eqn. (9) [31].

$L H V_{\text {gas }}=X_{C O} L H V_{C O}+X_{H 2} L H V_{H 2}+X_{C H 4} L H V_{C H 4}$

where, $\mathrm{X}=$ the mole fraction of each gas species.

The $L H V$ of the gas species are given as: [32]

$L H V_{C O}=13.1 \mathrm{MJ} / \mathrm{Nm}^{3}, \mathrm{LHVH} 2=11.2 \mathrm{MJ} / \mathrm{Nm}^{3}$, and $L H V_{C H 4}=37.1 \mathrm{MJ} / \mathrm{Nm}^{3}$.

The performance of the gasification process was measured in terms of the cold gas efficiency (CGE) [17]. The CGE is the fraction of the chemical energy of coal that is recovered in the cooled syngas. It was determined from the heating values and mass flow rates of the gasifier coal feed and product gas streams, according to Eqn. (10) [11].

$$
C G E=\left[\frac{L H V_{\text {gas }} \times \dot{Q}_{\text {gas }}}{L H V_{\text {coal }} \times \dot{m}_{\text {coal }}}\right] \times 100
$$

Where,

$L H V_{\text {gas }}=$ the lower heating value for the syngas

$L H V_{\text {coal }}=$ the lower heating value for coal feed

$Q_{\text {gas }}=$ the volume flow rate of the syngas

$m_{\text {coal }}=$ the mass flow rate of coal feed 


\section{RESULTS AND DISCUSSIONS}

\subsection{Producer gas composition}

Fig. 3 shows the variations in the contents of the producer gas as oxygen-air ratio varied from 0.21 to 1.0. As the oxygen content increased in the gasifying agent, the concentrations of all producer gas components increased except nitrogen that reduced to near zero. The initial high concentration of $\mathrm{N}_{2}$ in producer gas at low oxygen concentrations was majorly from the air used at the beginning of the experiment, as explained in section 3.2.

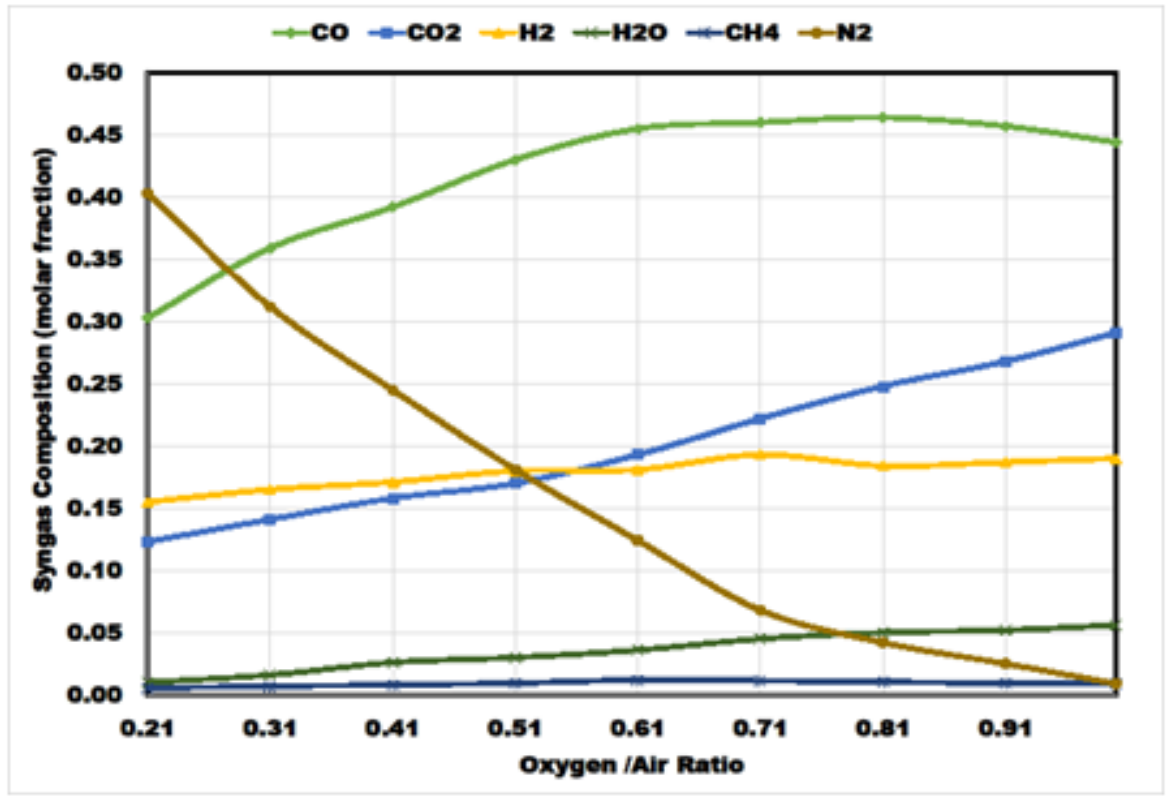

Fig. 3: Effect of oxygen/air ratio on producer gas composition

The increase in concentrations of $\mathrm{CO}$ was attributed to the fact that lower supply of $\mathrm{O}_{2}$ promoted partial oxidation reaction in Eqn. (2). However, as the $\mathrm{O}_{2}$ concentrations increased, the reactor temperature also increased (Fig. 7), and for a constant coal-feeding rate, the Boudouard reaction in Eqn. (4) occurred and consumed the $\mathrm{CO}_{2}$ generated from oxidation reaction in Eqn. (1). This led to the initial very limited rise in the concentrations of $\mathrm{CO}_{2}$ in the product gas at oxygen/air ratio below 0.5 . However, increased oxygen/air ratio beyond 0.5 led to increased concentrations of $\mathrm{CO}_{2}$ since excess supply of $\mathrm{O}_{2}$ enhanced combustion reactions in Eqn. (5) and Eqn. (1) in the reactor. This is consistent with the findings of Alina Zogala [11], Lee H et al [18] and YoungChan Choi et al [29]

Concentrations of hydrogen gas also rose and this was attributed to the water-gas (steam) 
reaction in Eqn. (3) and water-gas shift reaction, Eqn. (7) [34]. Both these reactions were enhanced by increased reactor temperatures and led to consumption of steam [35]. This explained why the amount of $\mathrm{H}_{2} \mathrm{O}$ remained low in the product gas even at higher oxygen concentrations; some of the steam produced from combustion was consumed to produce hydrogen gas. The slight increase in methane concentrations was attributed to steam-methane reforming reaction Eqn. (8), though this reaction was very limited since it requires slightly higher pressures to be significant.

\subsection{Gas Yield}

From Fig. 4, it was observed that gas yield increased with increasing values of oxygen/air ratio. Producer gas yield increased from $11.04 \mathrm{~m}^{3} / \mathrm{h}$ to $16.81 \mathrm{~m}^{3} / \mathrm{h}$ and syngas yield increased from $5.12 \mathrm{~m}^{3} / \mathrm{h}$ to $10.81 \mathrm{~m}^{3} / \mathrm{h}$ giving an average ratio of syngas to producer gas yield as 0.612 . This was because of, first, the significantly reduced nitrogen concentrations in the gasifying medium, and second, the improved yield in $\mathrm{CO}$ and $\mathrm{H}_{2}$ gases due to enhanced oxygen concentrations.

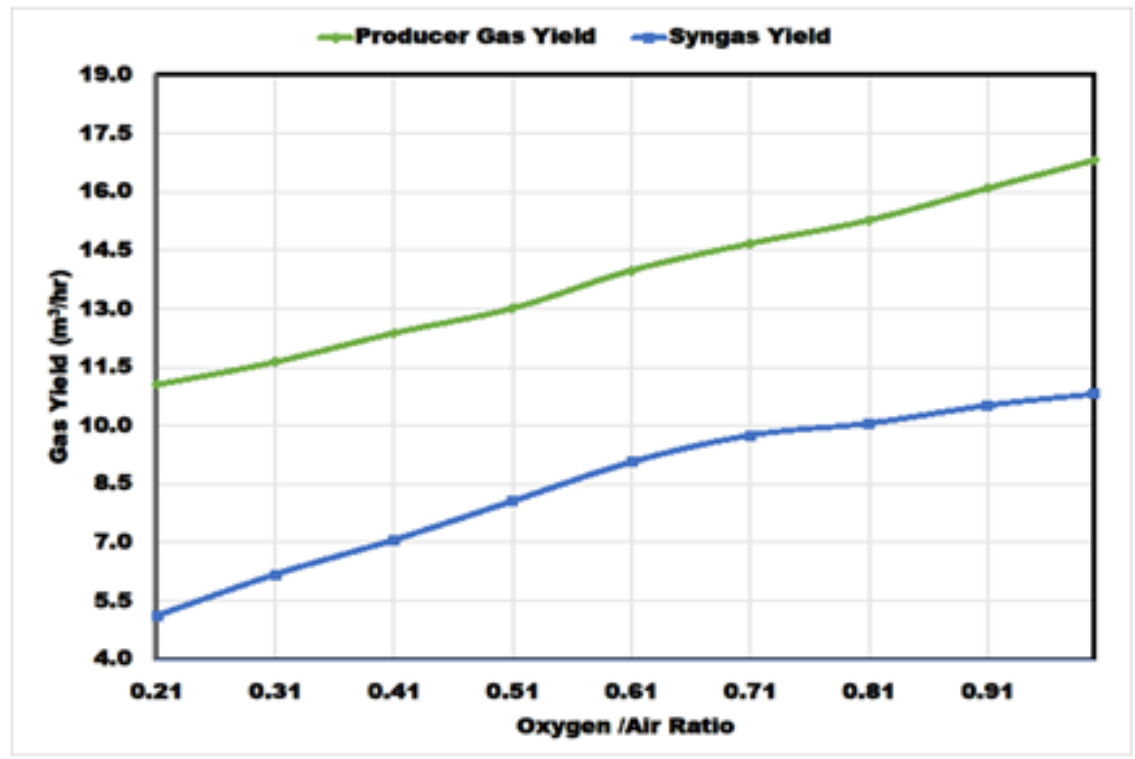

Fig. 4: Effect of oxygen/air ratio on producer gas and syngas yield 


\subsection{The syngas lower heating value (LHV)}

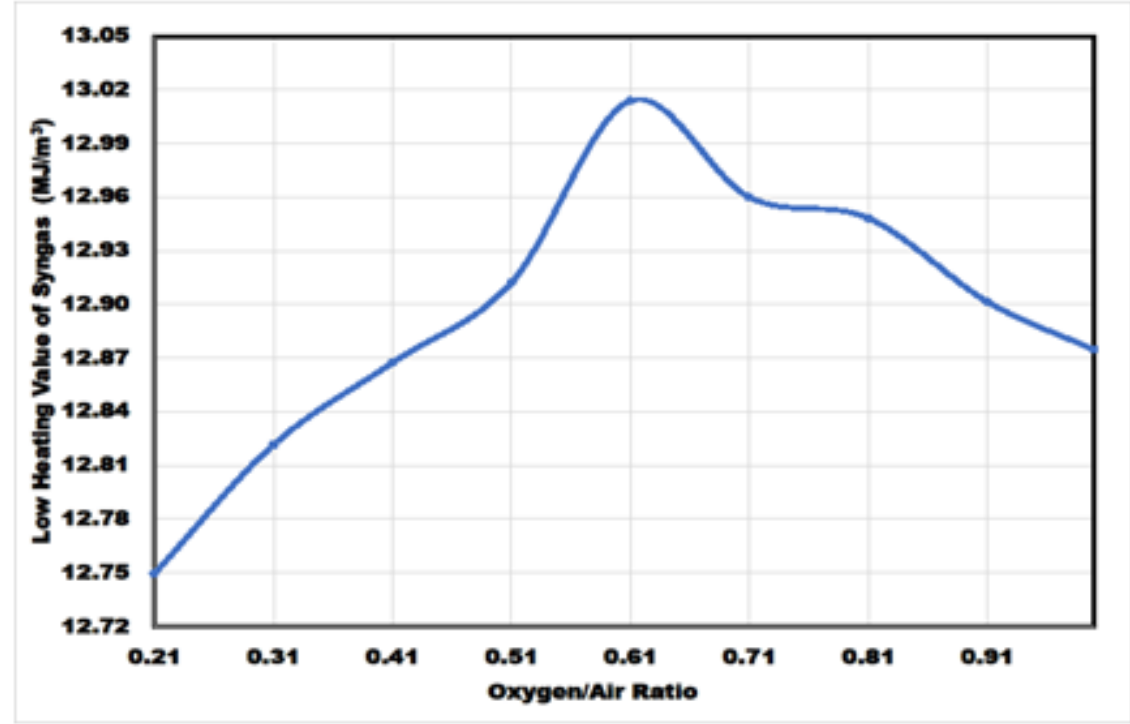

Fig. 5: Effect of oxygen/air ratio on low heating value of the gas

Increasing oxygen concentrations was also beneficial for the gasification since the LHV of the syngas increased from $12.75 \mathrm{MJ} / \mathrm{m}^{3}$ to $13.01 \mathrm{MJ} / \mathrm{m}^{3}$ as seen in Fig. 5. Increase in the LHV was explained by the increased yield in $\mathrm{CO}$ and $\mathrm{H}_{2}$ gases as well as a slight increase in the yield of $\mathrm{CH}_{4}$ gas. This trend agrees with the findings of Alina Zogala [11], though his values were a bit lower than those obtained herein. There was however, a slight drop in LHV at oxygen concentrations beyond 0.61 because of enhanced combustion reactions. The combustion reactions at these levels were attributed to increased availability of oxygen particles and elevated reactor temperatures.

\subsection{The Cold gas efficiency (CGE)}

The enhanced lower heating value of the syngas as well as the improved flow rate of the syngas due to increased concentrations of $\mathrm{CO}$ and $\mathrm{H}_{2}$, lead to improved cold gas efficiency [36] as shown in Fig. 6 consistent with . Cold gas efficiency increased from 36.6\% to $78.1 \%$ as oxygen/air ratio increased from 0.21 to 1.0 respectively. The increase in CGE was steeper up to the oxygen/air ratio of 0.61 beyond which the curve started becoming flatter. This was due to the enhanced gasification reactions at oxygen/air ratios below 0.61 compared to increased combustion reactions at oxygen/air above 0.61 . 


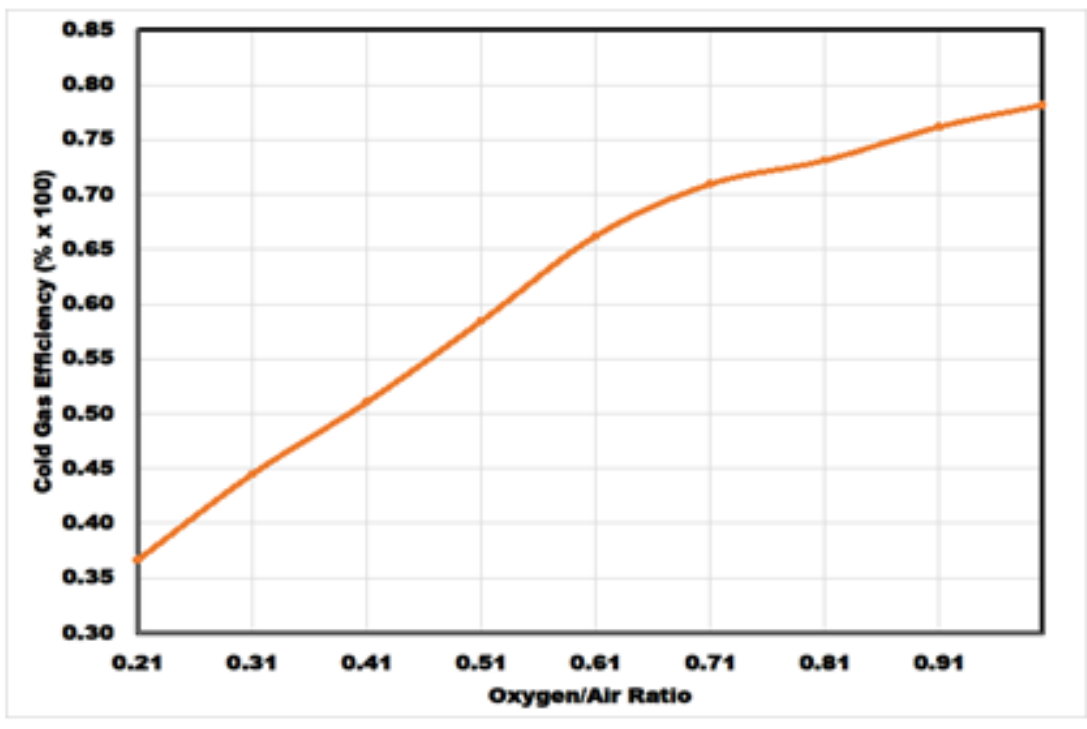

Fig. 6: Effect of oxygen/air ratio on cold gas efficiency

\subsection{Gasification Temperature}

On temperature variations, reactor temperature showed a slow increase initially at oxygen concentrations below 0.61 before exponentially increasing as oxygen concentrations approached 1.0, as seen in Fig. 7. The exponential increase was due to enhanced exothermic combustion reactions favored by the availability of the increasing amounts of oxygen consistent with observations made by Young-Chan Choi [29] and

The syngas outlet temperature also showed slight increase with increasing reactor temperature. However the values of syngas outlet temperatures were much lower than reactor temperature and this was attributed to the expansion that took place in freeboard area of the gasifier that led to reduction of temperature. Some of the heat may also have been lost through the wall of the freeboard section since it was not insulated. The reduced syngas temperatures were beneficial since it reduced the cost of processing the output gas. 


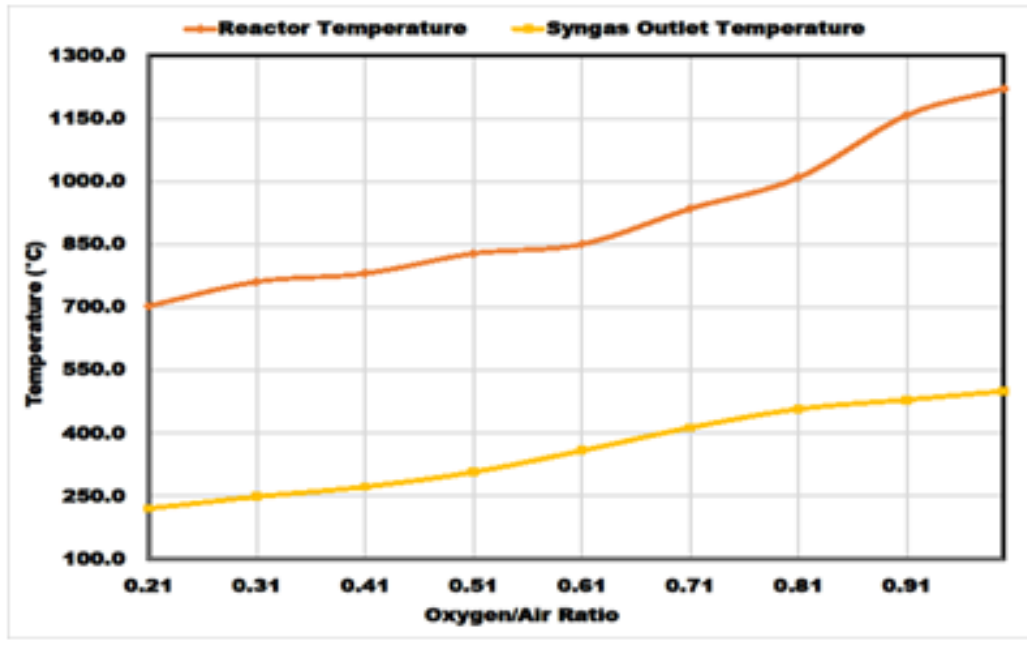

Fig. 7: Effect of oxygen/air ratio on reactor temperature and syngas outlet temperature

\section{CONCLUSIONS}

Oxygen-enriched air is a very good oxidizing medium for production of syngas for power plant applications since it contains much carbon monoxide and a moderate amount of hydrogen. The optimum amount of oxygen/air ratio for fixed-bed dry-fed gasifier was determined to be between 0.61 and 0.71 . Optimum reactor temperature was observed to be not more than $900^{\circ} \mathrm{C}$. The average producer to syngas yield was 0.612 . This research is useful for production of syngas for commercial as well as domestic use.

\section{ACKNOWLEDGEMENTS}

We thank Kenyan Government through National Research Fund, and Technical University of Mombasa for their funding towards this research. We also thank the Jomo Kenyatta University of Agriculture and Technology and Technical University of Mombasa communities for their support during this study.

\section{REFERENCES}

[1] David Yuko, The Status of Renewable Energy in Kenya: A study into the Status and Potential of Power Generation from Biomass Waste in Kenya. Institute for Research in Sustainable Energy and Development Nairobi, Kenya, (May 2004).

[2] Mehdi Najafi, Seyed Mohammad Esmaiel Jalali, Reza Khalo Kakaie, Farrokh Forouhandeh, "Prediction of cavity growth rate during underground coal gasification using multiple regression analysis," International Journal on Coal Science and 


\section{International Journal of Engineering Technology and Scientific Innovation}

ISSN: 2456-1851

Volume: 05, Issue: 04 "July-August 2020"

Technology, vol. 2(4), p. 318-324, (2015).

[3] Alessandro Clerici, Marcos Assayag, and Others, "World energy resources survey," technical report, World Energy Council, (2013).

[4] International Energy Agency Report, "Key world energy statistics," tech. rep., (2019).

[5] M.S. Alam, A.T. Wijayanta, K. Nakaso, and J. Fukai, "Syngas production from coal gasification with CO 2 rich gas mixtures," Cleaner Combustion and Sustainable World, Verlag Berlin Heidelberg and Tsinghua University Press, pp. 1103-1108, (2013).

[6] Francis Njoka, “Country report: Kenya’s Energy status, 2008-2010,” technical report.

[7] Mutemi Muthangya and David Samoei, "Status of water quality in the coal-rich muibasin on kitui county, kenya," ARPN Journal of Earth Sciences, vol. 1(2), pp. 48-51, (2012).

[8] Jale Gülen, Causes, Impacts and Solutions to Global Warming. Purdue University Press, (2014).

[9] Muthui, Richard K, Kabugu, M., Akisa, David M. and Rop, B. K., "Coal handling and equipment selection in Mui Basin, Kitui County, Kenya," Proceedings of International Conference on Sustainable Research and Innovation, vol. 5, pp. 87-90, (7th-9th May 2014).

[10] Jianxin Mi, N. Wang, M. Wang, P. Huo, D. Liu, "Investigation on the catalytic effects of AAEM during steam gasification and the resultant char reactivity in oxygen using Shengli lignite at different forms," International Journal on Coal Science and Technology, vol. 2(3), pp. 223-231, (2015).

[11] Alina Zogala, "Equilibrium simulations of coal gasification - factors affecting syngas composition," Journal of Sustainable Mining, vol. 13(2), pp. 30-38, (2014).

[12] Magdalena Cempa-Balewicz, M. Jacek Łączny, Adam Smoliński, Sebastian Iwaszenko, "Equilibrium model of steam gasification of coal," Journal of Sustainable Mining, vol. 12(2), pp. 21-28, (2013).

[13] Jin, H.; Lu, Y.; Liao, B.; Guo, L.; Zhang, X, “Hydrogen production by coal gasification in supercritical water with a fluidized bed reactor," International. Journal on Hydrogen Energy, pp. 7151-7160, (2010).

[14] Energy Regulatory Commission, "Updated least cost power development plan, study period: 2011-2031," tech. rep., Ministry Of Energy, Kenya, (March 2011)

[15] Alina Zogała, Tomasz Janoszek, "CFD simulations of influence of steam in gasification agent on parameters of UCG process," Journal of Sustainable Mining, vol. 14, pp. 2-11, (2015).

[16] Markus Blesl and Divid Bruchof, "Syngas production from coal," tech. rep., International Energy Agency, Enrgy Technology Systems Analysis Program (IEA ETSAP), (May 2010). 


\section{International Journal of Engineering Technology and Scientific Innovation}

ISSN: 2456-1851

Volume: 05, Issue: 04 "July-August 2020"

[17] John Dascomb, "Thermal Conversion Efficiency of Producing Hydrogen Enriched Synthesis Gas from Steam Biomass Gasification”. PhD Thesis, Dept. of Mechanical Engineering, Florida State University, (2013).

[18] H. Lee, S. Choi, and M. Paek, "A simple process modeling for a dry-feeding entrained bed coal gasifier," Proc. IMechE vol. 225 Part A: J. Power and Energy, vol. 225, pp. 111,(2011).

[19] T. J. Park, J. H. Kim, J. G. Lee, J. C. Hong, Y. K. Kim, Y. C. Choi, "Experimental studies on the characteristics of entrained flow coal gasifier," Energy Conversion Research Department, Korea Institute of Energy Research, (1998).

[20] Biagini E., Masoni L., Pannocchia G., and Tognotti L., "Development of gasifier models for hydrogen production optimization," AIDIC Conference Series, vol. 9, pp. 45- 52, (June, 2009).

[21] Babu B. V, Pratik N. Sheth, "Modeling and simulation of biomass gasifier: Effect of oxygen enrichment and steam to air ratio," Chemical Engineering Group, Birla Institute of Technology and Science, Pilani, Rajasthan, India, (2003).

[22] Haibin Li, Yu Yu, Minfang Han, Ze Leii, "Simulation of coal char gasification using oxygen/carbon dioxide ," International Journal Coal Science and Technology, vol. 1(1), pp. 81-87, (2014).

[23] Weihong Yang, Anna Ponzio, Carlos Lucas, Wlodzimierz Blasiak, "Performance analysis of a fixed-bed biomass gasifier using high-temperature air," Journal on Fuel Processing Technology, vol. 87, pp. 235 - 245, (2006).

[24] Idowu Adeyemi, Thomas Arink, Isam Janajreh, "Numerical modeling of the entrained flow gasification (EFG) of kentucky coal and biomass," Energy Procedia journal, vol. 75, pp. 232-239, (2015).

[25] Leila Emami Taba, Muhammad Faisal Irfan, Wan Ashri Mohd Wan Daud, Mohammed Harun Chakrabarti, "The effect of temperature on various parameters in coal, biomass and co-gasification: A review," Der Chemica Sinica, vol. 16, pp. 5584-5596, (2012).

[26] Muhammad Shahbaz, Suzana Yusup, Abrar Inayat, David Onoja Patrick, Angga Pratama, "Application of response surface methodology to investigate the effect of different variables on conversion of palm kernel shell in steam gasification using coal bottom ash," Journal of Applied Energy, Elsevier, pp. 1 - 9, (2016), http://dx.doi.org/10.1016/j.apenergy.2016.05.045.

[27] Shabbar Syed, "Thermodynamics equilibrium analysis of gasification," International Journal of Thermal and Environmental Engineering, vol. 4 (1), pp. 47-54, (2012).

[28] Jorge E. Preciado, John J. Ortiz-Martinez, Juan C. Gonzalez-Rivera, Rocio SierraRamirez and Gerardo Gordillo, "Simulation of synthesis gas production from steam oxygen gasification of colombian coal using Aspen Plus," Journal on Energies, vol. 5, pp. 
International Journal of Engineering Technology and Scientific Innovation

ISSN: 2456-1851

Volume: 05, Issue: 04 "July-August 2020"

4924-4940, (2012).

[29] Young-Chan Choi, Tae-Jun Park, Jae-Ho Kim, Jae-Goo Lee, Jae-Chang Hong and YongGoo Kim, "Experimental studies of 1 ton/day coal slurry feed type oxygen blown, entrained flow gasifier," Korean Journal on Chemical Engineering, vol. 18(4), pp. 493498, (2001).

[30] Bingxi Li, Zhongbin Fu, Yaning Zhang, Hui Liu, and Bo Zhang, "Simulation analysis of biomass gasification in an autothermal gasifier using aspen plus," Cleaner Combustion and Sustainable World, Verlag Berlin Heidelberg and Tsinghua University Press, pp. 479 - 483, (2013), doi 10.1007/978-3-642-30445-366.

[31] Daniela Tasma, Tanase Panait, "The quality of syngas produced by fluidized- bed gasification using sunflower husk," The Annals of "Dunarea de Jos" University of Galati, vol. 5, pp. 33 - 36, (2012).

[32] Reed T. B., Das A., Handbook of Biomass Downdraft Gasifier Engine Systems,. John Wiley and Sons Inc., seri/sp- 271-3022 de88001135. US. Department of Energy, solar energy research institute ed., (1988).

[33] Cristina Botero, Randall P. Field, Howard J. Herzog, Ahmed F. Ghoniem, "On the thermal and kinetic performance of a coal-carbon dioxide slurry-fed gasifier: Optimization of carbon dioxide and steam flow using carbon dioxide skimming and steam injection," 38th International Technical Conference on Clean Coal and Fuel Systems, Clearwater (FL), USA, vol. 2(6), pp. 1-15, (2013).

[34] Thanasit Wongsiriamnuay, and Nakorn Tippayawong, "Product gas distribution and composition from catalyzed gasification of mimosa," INTERNATIONAL JOURNAL of RENEWABLE ENERGY RESEARCH, pp. 363-368, (2012).

[35] M. Pohorely, M. Vosecky, P. Hejdova, M. Puncochar, S. Skoblja, M. Staf, J. Vosta, B. Koutsky, K. Svoboda, "Gasification of coal and pet in fluidized bed reactor," Fuel, pp. 2458-2468, (2006).

[36] Shayan Karimipour a, Regan Gerspacher b, Rajender Gupta, Raymond J. Spiteri, "Study of factors affecting syngas quality and their interactions in fluidized bed gasification of lignite coal," Fuel, pp. 1-13, (2012). 